\title{
Effects of Ultraviolet Radiation on Recycled and Virgin HDPE Corrugated Pipes Used in Road Drainage Systems
}

\section{Khanh Q. Nguyen}

University of Sherbrooke: Universite de Sherbrooke

\section{Patrice Cousin}

University of Sherbrooke: Universite de Sherbrooke

\section{Khaled Mohamed}

University of Sherbrooke: Universite de Sherbrooke

Mathieu Robert ( $\nabla$ mathieu.robert2@usherbrooke.ca)

University of Sherbrooke: Universite de Sherbrooke https://orcid.org/0000-0003-0943-1715

\section{Adel El-Safty}

University of North Florida

\section{Brahim Benmokrane}

University of Sherbrooke: Universite de Sherbrooke

\section{Research Article}

Keywords: High-density polyethylene (HDPE) pipe, recycled and virgin pipes, UV aging, road drainage systems, chemical, morphological structure, and thermomechanical properties

Posted Date: November 5th, 2021

DOI: https://doi.org/10.21203/rs.3.rs-978155/v1

License: (9) (1) This work is licensed under a Creative Commons Attribution 4.0 International License. Read Full License

Version of Record: A version of this preprint was published at Journal of Polymers and the Environment on April 6th, 2022. See the published version at https://doi.org/10.1007/s10924-022-02437-x. 


\section{Abstract}

High-density polyethylene (HDPE) pipe is one of the materials of interest for use in road drainage systems. The combination of ultraviolet (UV) light, temperature, and moisture can produce weak spots and lead to pipe degradation during the storage, installation, and repair process. The objective of this study was to evaluate changes in the chemical, morphological structure, and thermomechanical properties of recycled and virgin pipes under UV exposure. Laboratory accelerated aging tests were conducted by exposing pipes to UV for 3600 hours with an irradiance of $0.89 \mathrm{~W} /\left(\mathrm{m}^{2} \mathrm{~nm}\right)$ at a wavelength of $340 \mathrm{~nm}$. A cycle of 12 hours -comprised of 8 hours of UV radiation at $60^{\circ} \mathrm{C}$ and 4 hours of no UV radiation at $50^{\circ} \mathrm{C}$ corresponding to no water condensation-was performed to condition the specimens. HDPE specimens were taken out after 3600 hours and analyzed with FTIR (Fourier-transform infrared spectroscopy), SEM (scanning electron microscopy), DSC (differential scanning calorimetry), oxidative-induction time (OIT) measurements, and tensile tests. The results show that the recycled pipes maintained good properties and were not significantly affected by UV radiation, similarly to the virgin pipes. Statistical analysis using one-way analysis of variance (ANOVA) shows that there was no significant difference between tensile strength, elastic modulus, and hardness measurements before and after UV exposure. There were only a few small changes in the surface of the pipes. The addition of carbon black, antioxidants, and UV stabilizers prevented further aging of the pipes during UV exposure.

\section{Introduction}

In recent years, thermoplastic pipes have become one of the most widely used materials for culverts and other highway applications [1]. High-density polyethylene (HDPE) is one of the materials of interest for these applications due to its numerous advantages. HDPE pipes are generally lighter, more flexible, and easier to install than other types of pipes as well as involving entail low maintenance costs and greater resistance to chemical attack [2-6]. Once the manufacturing process has been completed, however, pipes are often stored outdoors for a period of time before being installed. During the storage, installation, and repair process, the combination of ultraviolet (UV) light, temperature, and moisture can produce weak spots and lead to pipe degradation. The presence of impurities during the manufacturing process causes the pipes to absorb UV radiation. Since PE materials only contain $\mathrm{C}-\mathrm{C}$ and $\mathrm{C}-\mathrm{H}$ bonds, they are considered to be easily susceptible to degradation when exposed to high temperatures and UV radiation [7]. Culverts used in road drainage systems incur damage to their end openings due to UV radiation [7-9]. UV degradation can alter the physicomechanical, chemical, and macromolecular structure of the polymer [10,11]. This degradation can alter color, tensile strength, elastic modulus, and impact strength of the materials $[9,12]$. The presence of free radicals leads to chain scission, which usually takes place in the amorphous phase and at the amorphous-lamellar interface [13], whereas the crystalline phase remains inert [14]. In fact, UV stabilizers such as carbon black are integrated into pipes to prevent UV-induced reactions. In general, BNQ 3624-120 (2016) [15] and ASTM D4218 (2015) [16] require a minimum of 2-4\% carbon black in pipes. Carbon black helps protect pipes against UV-radiation damage by limiting penetration to the external surface of the pipe wall (corrugated parts). 
Attwood et al. (2006) studied the effects of UV degradation on recycled polyolefin blends. Tests were performed using QUV accelerated weathering testers with an irradiance of $0.68 \mathrm{w} / \mathrm{m}^{2}$ at $340 \mathrm{~nm}$. The process included 8 hours of UV radiation at $60^{\circ} \mathrm{C}$ and 4 hours of condensation at $50^{\circ} \mathrm{C}$. Test exposure time was 1000 to 5000 hours. The results showed that UV radiation had little effect on tensile, impact, and chemical properties; melt flow tests; gloss; and color analyses. Some surface changes were, however, observed [17].

Maria et al. (2011) studied the impact of UV radiation on PE pipes under IR-microscopy. The samples tested contained a phenolic stabilizer (Irganox 1010) as a primary antioxidant, a processing stabilizer (Irgafos 168), carbon black, and UV stabilizers. The specimens were exposed to UV radiation for 144 to 2208 hours. IR-microscopy and OIT measurements revealed loss of the phenolic antioxidant Irganox 1010 in the outer pipe wall. No changes in the degree of crystallinity were noted [18].

Jassim et al. (2017) evaluated the tensile strength at break of medium-density polyethylene (MDPE) water pipes made with and without carbon black after exposure to UV radiation for 200 hours. The results showed that the tensile strength at break for MDPE pipe made with carbon black was higher that of than virgin MDPE pipe. The tensile strength at break after exposure to UV radiation was unchanged, however, due to the carbon black playing a key role as a UV stabilizer [19].

Jiang et al. (2019) investigated the influence of UV absorbers on the UV resistance of HDPE. They concluded that the HDPE samples maintained their thermal and mechanical properties after exposure to UV irradiation for 600 hours under the aging condition of $0.51 \mathrm{w} / \mathrm{m}^{2}$ and a wavelength of $350 \mathrm{~nm}$. In addition, slight changes in crystallinity were noted before and after exposure to UV radiation [20].

The incorporation of UV stabilizers, carbon black, and antioxidants in the polymer matrix helps limit the impact of UV radiation on the properties of materials. Past studies, however, have focused on HDPE films or HDPE water pipes. In contrast, very little has been developed about the effect of UV radiation on corrugated HDPE pipes used in road drainage systems. In addition, the current use of recycled HDPE pipes is of interest due to their sustainability and cost-effectiveness as compared to virgin pipes [6, 21-24]. Recycling products can reduce the carbon footprint, the use of raw materials, energy requirements, water consumption, and greenhouse-gas emissions in the production process $[25,26]$. The main objective of our study was to assess the effect of UV radiation on the properties of recycled and virgin corrugated HDPE pipes used in road drainage systems. The techniques FTIR (Fourier-transform infrared spectroscopy) and SEM (scanning electron microscopy) were used to investigate the formation of degradation and any changes in pipe-wall morphological parameters. The thermal properties and crystallinity of the HDPE pipes were assessed with DSC (differential scanning calorimetry). The OIT measurements were conducted to profile antioxidant concentrations. In addition, the mechanical properties of the recycled and virgin HDPE corrugated pipessuch as tensile strength and hardness-were investigated before and after accelerated UV exposure.

This study is a part of ongoing research between the University of Sherbrooke and Quebec's Ministry of Transportation (MTQ) to jointly investigate the short- and long-term performance of new corrugated HDPE pipes made with or without recycled resins for use in road drainage systems under North American climate 
conditions. The study included six new corrugated HDPE pipes from three different North American manufacturers, including three HDPE pipes made with virgin resins and three HDPE pipes made with recycled resins.

\section{Experimental Methods 2.1. Material}

Six new corrugated HDPE pipes used in non-pressure road drainage systems (e.g., storm drainage and storm sewers) were provided by North American manufacturers. The pipes contained $2-4 \%$ carbon black: two were manufactured with post-consumer recycled resins (A-R and D-R); one with post-industrial recycled resins (B-R); and three with virgin resins ( $A-V, B-V, C-V)$. The letters $A, B, C$, and $D$ designate the manufacturers; $R$ stands for recycled resin and $V$ for virgin resin. Post-consumer recycled (PCR) materials are waste materials discarded by consumers and reused in new pipes. The recycling process involves shredding, washing, homogenizing, and pelletizing. Post-industrial recycled (PIR) materials are pipe scrap generated during the manufacturing process. Regrind pipe is produced by shredding, mixing with the raw material, and drawing by extrusion without changing the process parameters. This type of regrind can be considered a pseudo-source of recycled resins. Each pipe measured $900 \mathrm{~mm}$ in diameter and $3000 \mathrm{~mm}$ in length. Table 1 provides the pipe properties. 
Table 1

Properties of the investigated HDPE pipes

\begin{tabular}{|c|c|c|c|c|c|c|c|}
\hline \multirow[t]{2}{*}{ Property } & \multirow{2}{*}{$\begin{array}{l}\text { Method } \\
\text { (ASTM) }\end{array}$} & \multicolumn{6}{|c|}{ Specimen } \\
\hline & & $A-R$ & $A-V$ & B-R & B-V & $C-V$ & D-R \\
\hline Density $\left(\mathrm{g} / \mathrm{cm}^{3}\right)$ & D792-13 [27] & 0.988 & 0.977 & 0.976 & 0.987 & 0.976 & 0.964 \\
\hline MFI (g/10 min) & D1238-13 [28] & 0.103 & 0.077 & 0.066 & 0.061 & 0.115 & 0.058 \\
\hline $\begin{array}{l}10^{-3} \mathrm{M}_{\mathrm{n}} \text { molecular weight } \\
\left(\mathrm{gmol}^{-1}\right)\end{array}$ & - & 11.9 & 7.3 & 9.5 & 8.3 & 5.4 & 9.0 \\
\hline $\begin{array}{l}10^{-3} \mathrm{M}_{\mathrm{w}} \text { molecular weight } \\
\left(\mathrm{gmol}^{-1}\right)\end{array}$ & - & 405 & 323 & 542 & 413 & 449 & 392 \\
\hline $\mathrm{CB}(\%)$ content & $\begin{array}{l}\text { D5805-00-19 } \\
\text { [29] }\end{array}$ & 3.0 & 2.8 & 3.0 & 2.5 & 2.5 & 3.2 \\
\hline Hardness (HD) & - & 56 & 55 & 55 & 60 & 65 & 61 \\
\hline Softening temperature by DMA & - & 54 & 52 & 45 & 45 & 52 & 58 \\
\hline Softening temperature by TMA & - & 51 & 50 & 45 & 45 & 45 & 54 \\
\hline Mass loss $\left({ }^{\circ} \mathrm{C}\right)$ & E2550-17 [30] & 390 & 375 & 415 & 420 & 413 & 413 \\
\hline Tensile strength (MPa) & D638-14 [31] & 25.12 & 23.58 & 18.83 & 17.44 & 19.81 & 22.56 \\
\hline \multicolumn{8}{|c|}{$\begin{array}{l}\text { Note: } \mathrm{MFI}=\text { Melt flow index; } \mathrm{CB}=\text { carbon black; DMA = dynamic mechanical analysis; } \mathrm{TMA}= \\
\text { thermomechanical analysis, ASTM = American Society for Testing and Materials. }\end{array}$} \\
\hline
\end{tabular}

Small specimens ( $15 \mathrm{~mm} \times 15 \mathrm{~mm}$ ) were cut from the corrugated part of the pipes with the exception of tensile specimens. To avoid bending due to the shape of the corrugated part and facilitate cutting, the tensile specimens were taken from the pipe liner (Fig. 1). The specimens cut from the corrugated parts of pipes A-R, A-V, B-R, B-V, C-V, and D-R were 7.30, 7.30, 7.80, 7.80, 3.25, and $4.50 \mathrm{~mm}$ thick, respectively. The tensile specimens cut from pipes A-R, A-V, B-R, B-V, C-V, D-R were 4.80, 4.40, 7.50, 7.60, 2.70, and $3.80 \mathrm{~mm}$ thick, respectively. The sections below provide details about specimen shape and dimensions.

\subsection{UV aging}

Specimens were placed under fluorescent UVA in a test chamber that simulates the spectral irradiance of daylight, as shown in Fig. 2. To reduce the effect of humidity on the UV aging of the pipes, the cycles for irradiance of $0.89 \mathrm{~W} /\left(\mathrm{m}^{2} \mathrm{~nm}\right)$ at a wavelength of $340 \mathrm{~nm}$ in accordance with ASTM D4329 (2013), procedure A [32], were modified in our study. Specimen conditioning consisted of a 12-hour cycle, comprised of 8 hours of UV radiation at $60^{\circ} \mathrm{C}$ and 4 hours with no UV radiation at $50^{\circ} \mathrm{C}$, corresponding to no water condensation. The text exposure time was 3600 hours. 


\subsection{Spectroscopy analysis}

Fourier-transform infrared spectroscopy (FTIR-4600 spectrometer) was used to assess the changes in chemical structure in the HDPE pipes before and after exposure to UV radiation. With the device in attenuated total reflection (ATR) mode, a single spectrum of 32 scans was recorded at a resolution of 4 $\mathrm{cm}^{-1}$. A rectangular specimen $(15 \mathrm{~mm} \times 15 \mathrm{~mm})$ was analyzed over the 4000 to $1000 \mathrm{~cm}^{-1}$ wavenumber range. The test specimen thickness corresponding to the pipe wall thickness (corrugated part) was 7.30, $7.30,7.80,7.80,3.25$, and $4.50 \mathrm{~mm}$ for A-R, A-V, B-R, B-V, C-V, and D-R, respectively. The FTIR spectra of the specimens before UV exposure are considered the reference spectra. The surface spectra in direct (top) and nondirect (bottom) UV exposure through the specimen thickness were analyzed and compared to the reference spectra.

\subsection{Microscopy observation}

Scanning electron microscope (SEM) observations were carried out on a Hitachi S-4700 at a voltage of $5 \mathrm{kV}$. Our study investigated the surface morphologies of unexposed and UV-exposed HDPE specimens ( $15 \mathrm{~mm} \mathrm{x}$ $15 \mathrm{~mm}$ ). The specimens received a palladium-gold coating prior to analysis to prevent charging. Moreover, energy dispersive spectrometry (EDS) was then conducted to study the chemical composition of certain pipes.

\subsection{Thermal analysis}

The melting point and melting enthalpy of the HDPE pipes were determined with a differential scanning calorimetry device (DSC 6000 from Perkin-Elmer). Specimens of 5 to $10 \mathrm{mg}$ were cut from both unexposed and UV-exposed HDPE pipe specimens. The measurement was performed under nitrogen at a scanning rate of $20^{\circ} \mathrm{C} / \mathrm{min}$ from $30^{\circ} \mathrm{C}$ to $205^{\circ} \mathrm{C}$. The melting point and melting enthalpy were determined by drawing a baseline below the melting peak. The degree of crystallinity was calculated from the ratio of the melting enthalpy of the specimens to the melting enthalpy of $100 \%$ crystalline polyethylene $(287 \mathrm{~J} / \mathrm{g})$ [33].

The OIT of the unexposed and UV-exposed HDPE pipe specimens was measured with differential scanning calorimetry (DSC 6000 by Perkin-Elmer) in accordance with ASTM D3895 (2019) [34]. A 5 to $10 \mathrm{mg}$ specimen was heated from room temperature to $200^{\circ} \mathrm{C}$ at a rate of $30^{\circ} \mathrm{C} / \mathrm{min}$ under nitrogen. After an isotherm of 1 minute, the gas was switched to oxygen. After some time, an exothermic peak appeared and the time corresponding to the onset was taken as the OIT value. Figure 3 provides a typical OIT assessment from a recorded time-based thermal curve.

\subsection{Mechanical testing}

The tensile properties of HDPE pipes were evaluated according to ASTM D638 (2014) [31] with dog-bone specimens. Tensile specimens were punched directly from the pipe liner with a stainless-steel die. The specific geometry of the specimens is described in detail in ASTM D638 (2014) and illustrated in Fig. 4. This test was conducted at $23^{\circ} \mathrm{C}$ with an MTS universal testing machine equipped with a $5 \mathrm{kN}$ load cell. A constant crosshead speed was maintained at $50 \mathrm{~mm} / \mathrm{min}$. A $634.12 \mathrm{~F}-24$ extensometer was used to measure sample extension. The stress-strain curve of the unexposed and UV-exposed HDPE specimens 
was reported after five replicates. The average tensile, elastic modulus values, and standard deviation were determined for each pipe.

The hardness of specimens before and after exposure to UV radiation was measured by a Shore hardness durometer using the D (HD) scale according to ASTM D2240 (2015) [35]. This digital durometer has an impact rod with a $30^{\circ}$ conical point. The force was applied manually for 15 seconds and the hardness value recorded. A rectangular specimen $(15 \mathrm{~mm} \times 15 \mathrm{~mm})$ with a thickness not less than $6 \mathrm{~mm}$ was used. Three specimens for each pipe and three readings at three different locations were recorded for each specimen. The average value of each specimen is presented herein.

\section{Results}

\subsection{FTIR analysis}

FTIR analysis was performed to assess the degree of degradation. Figures $5 a, b, c, d$, e, and $f$ show the FTIR spectra of unexposed and UV-exposed HDPE specimens after 3600 hours of aging. For all specimens before and after exposure to UV radiation, the spectra show typical bands of $\mathrm{C}-\mathrm{H}$ groups at $2913 \mathrm{~cm}^{-1}$ and 2847 $\mathrm{cm}^{-1}$, attributed to asymmetric and symmetric stretching vibrations, respectively. The presence of bending vibrations from the $\mathrm{CH}_{2}$ is visible at $1465 \mathrm{~cm}^{-1}$ [36]. Based on the results, the top and bottom surfaces of specimens before UV exposure presented the same chemical structure. There were no differences between pipes made with recycled or virgin resin. This observation is quite similar to specimens after UV exposure. In contrast, peaks of very low intensity at $1717 \mathrm{~cm}^{-1}$ and $1140 \mathrm{~cm}^{-1}$, corresponding to the presence of $\mathrm{C}-\mathrm{O}$ or $\mathrm{C}=\mathrm{O}$ groups, were detected upon oxidation at the top surface compared to specimens before UV exposure [37]. In addition, the presence of a very small peak corresponding to $\mathrm{O}-\mathrm{H}$ groups was observed at $3380 \mathrm{~cm}^{1}$

after UV exposure. It can be concluded that UV exposure produced very small structural modifications on the top surface caused by oxidation. These light changes can in no way induce modifications that would affect material integrity.

\subsection{SEM/EDS analysis}

SEM analysis of the surface of the HDPE pipes before and after exposure was carried out to observe any changes caused by UV radiation (Fig. 6). In general, as the SEM micrographs show, the specimen surfaces were relatively smooth at scan widths of $100 \mu \mathrm{m}$ and $10 \mu \mathrm{m}$ before UV exposure. After 3600 hours of irradiation, the specimen surface at the scan width of $100 \mu \mathrm{m}$ evidenced no morphological changes. At the scan width of $10 \mu \mathrm{m}$, some cracks were observed on the surface of pipes A-V and D-R, possibly due to UV radiation. These microcracks only occurred on one light area (contaminant) of the sample surfaces and not on the darkest areas (resin). EDS (energy dispersive spectrometry) analysis revealed that these two areas had different chemical compositions (Fig. 7). The darkest areas were constituted of elements in the resin compound (mainly carbon); the lightest areas contained nitrogen, sulfur, and oxygen. Consequently, it may be assumed that the cracked areas did not result from the PE but rather from a contaminant probably 
deposited during the manufacturing process. The results are then quite consistent with the findings from FTIR analysis.

\subsection{Thermal behavior}

Specimens before and after UV exposure were studied in order to investigate thermal properties and primarily the degree of crystallinity. The melting point and melting enthalpy of the HDPE pipes were measured with DSC. The degree of crystallinity was calculated from the ratio of the melting enthalpy of the specimens to the melting enthalpy of $100 \%$ crystalline polyethylene $(287 \mathrm{~J} / \mathrm{g}$ ), as shown in Table 2 . The results show that the melting point decreased $\left(3^{\circ} \mathrm{C}\right.$ to $\left.9^{\circ} \mathrm{C}\right)$ after 3600 hours of UV exposure. As a result, a slight decrease of $0-4 \%$ of the melting enthalpy value resulted in a slight decrease of $0-4 \%$ crystallinity. It should be noted that photo-oxidative degradation usually takes place in the amorphous phase and in the amorphous-lamellar interface of the semicrystalline polymer $[13,38]$. In fact, the incorporation of antioxidants into pipes prevents the formation of free radicals during the manufacturing process. Hence, they prevent the degradation of pipes exposed to UV radiation.

Table 2

Melting temperature and crystallinity of the HDPE pipes before and after UV exposure

\begin{tabular}{|lllllll|}
\hline Specimen & \multicolumn{3}{l}{ Before UV Exposure } & \multicolumn{3}{l|}{ After UV Exposure } \\
\cline { 2 - 7 } & $\begin{array}{l}\text { Melting } \\
\text { point } \\
\left({ }^{\circ} \mathrm{C}\right)\end{array}$ & $\begin{array}{l}\text { Melting } \\
\text { enthalpy } \\
(\mathbf{J} / \mathbf{g})\end{array}$ & $\begin{array}{l}\text { Degree of } \\
\text { crystallinity } \\
(\%)\end{array}$ & $\begin{array}{l}\text { Melting } \\
\text { point }\end{array}$ & $\begin{array}{l}\text { Melting } \\
\text { enthalpy } \\
(\mathbf{J})\end{array}$ & $\begin{array}{l}\text { Degree of } \\
\text { crystallinity } \\
(\%)\end{array}$ \\
\hline A-R & 153 & 135 & 47 & $\begin{array}{l}\left.{ }^{\circ} \mathrm{C}\right) \\
(\mathrm{J})\end{array}$ & 132 & 46 \\
\hline A-V & 153 & 139 & 49 & 144 & 137 & 48 \\
\hline B-R & 143 & 102 & 36 & 138 & 105 & 36 \\
\hline B-V & 144 & 132 & 46 & 138 & 131 & 45 \\
\hline C-V & 151 & 151 & 53 & 146 & 147 & 51 \\
\hline D-R & 148 & 149 & 52 & 145 & 143 & 50 \\
\hline
\end{tabular}

OIT is commonly used to evaluate the thermal-oxidative resistance of polymers and the depletion rate of antioxidants in their products [39-41]. Our study took OIT measurements to investigate the depletion rate of antioxidants of unexposed and UV-exposed HDPE specimens. Table 3 shows a decrease in OIT values after 3600 hours of UV exposure. The OIT decrease indicates the consumption of antioxidants in pipes. The reduction also depends on the thickness of the HDPE specimens. The difference between the OIT values of the exposed direct (top) and indirect (bottom) surface depends on specimen thickness, as shown in Table 3. This difference is clear with the specimens 7.30 and $7.80 \mathrm{~mm}$ in thickness. In contrast, there were no differences in OIT between the two sides in the thinner 3.25 and $4.50 \mathrm{~mm}$ samples. It should be pointed out that the initial OIT values between pipes were different, assessed based on the initial antioxidant content and type in each pipe. This information is a professional secret and was unavailable to the authors. In 
addition, it can be concluded that all the investigated pipes met the OIT minimum of 20 minutes in ASTM D3895 (2019) [34], in which the antioxidant content was sufficient to withstand oxidation by UV radiation. The results of OIT measurements are in good agreement with the FTIR, SEM, and DSC analyses, in which antioxidants are consumed and prevent pipe degradation during UV exposure.

Table 3

OIT values of HDPE pipes before and after exposure to UV

\begin{tabular}{|lllll|}
\hline Specimen & Thickness $(\mathbf{m m})$ & OIT $(\mathbf{m i n})$ - Before UV Exposure & \multicolumn{2}{l|}{ OIT (min) - After UV Exposure } \\
\cline { 4 - 5 } & & & Top surface & Bottom surface \\
\hline A-R & 7.30 & 90 & 52 & 71 \\
\hline A-V & 7.30 & 87 & 51 & 74 \\
\hline B-R & 7.80 & 103 & 62 & 79 \\
\hline B-V & 7.80 & 106 & 58 & 70 \\
\hline C-V & 3.25 & 33 & 23 & 24 \\
\hline D-R & 4.50 & 86 & 67 & 68 \\
\hline
\end{tabular}

\subsection{Mechanical behavior}

The tensile test of specimens was carried out to determine the tensile strength and elastic modulus of the HDPE pipes. Figures $8 a, b, c, d, e$, and $f$ present the typical stress-strain curves for unexposed and UVexposed HDPE specimens with five replicates for each pipe. The figures show that the stress-strain behavior of the pipes was governed by three regions: (1) elastic (linear and nonlinear), (2) neck propagation, and (3) plastic regions. The initial portion of the stress-strain curve is defined as the elastic deformation region where the elastic modulus is defined as the slope of the stress-strain curve. The maximum point on the stress-strain curve is called the yield point. The area corresponding to the reduced stress value is often called a neck. The area with relatively stable stress values is the development phase of the neck. The initial tensile strength of pipes A-R, A-V, B-R, B-V, C-V, and D-R pipes was 25.12, 23.58, 18.83, 17.44, 19.81, and $22.56 \mathrm{MPa}$, respectively. After 3600 hours of UV radiation, the tensile strength of the popes remained almost unchanged at 23.39, 23.19, 18.45, 17.40, 19.79, and 22.36 MPa for pipes A-R, A-V, B-R, B-V, C-V, and D-R pipes, respectively (Fig. 9a). Figures $8 a, b, c, d, e$, and $f$ show that the elongation of all specimens was more than $4.0 \mathrm{~mm} / \mathrm{mm}$ before UV exposure. After exposure to UV radiation for 3600 hours, the elongation at break of specimens $B-R$ and $B-V$ remained at $4.0 \mathrm{~mm} / \mathrm{mm}$, but this value varied for the other specimens. The elongation at break of specimens A-R, A-V, C-V, D-R was 1.5 to $2.9 \mathrm{~mm} / \mathrm{mm}, 0.8$ to $3.5 \mathrm{~mm} / \mathrm{mm}, 0.5$ to 1.65 $\mathrm{mm} / \mathrm{mm}$, and 0.9 to $3.2 \mathrm{~mm} / \mathrm{mm}$, respectively. The UV radiation did not significantly affect the tensile strength of the pipes. Figures $8 a, b, c, d, e$, and $f$ show a variation in the elongation values at break. The behavior also varied from one manufacturer to the next and from one specimen to next from the same manufacturer. The pipes from manufacturers $A, C$, and D did not have uniform behavior in that they more fragile than those from manufacturer $B$. Figure $9 \mathrm{~b}$ provides the elastic modulus of the specimens, showing that the elastic modulus of all the specimens decreased after UV exposure for 3600 hours. The standard 
deviation of the calculations was, however, relatively large for specimens A-R, C-V, and D-R. In fact, the addition of antioxidants and carbon black further inhibited the effect of UV radiation.

Table 4 gives the results of the hardness analysis; hardness was measured with a Shore D durometer. Table 4 shows that a slight decrease in hardness was observed for all specimens. For semicrystalline polymers such as HDPE, the factors affecting hardness act mainly on the crystalline region. In fact, polymer chains in the crystalline region are denser than those in the amorphous region [42]. Consequently, the slight differences in hardness values between the HDPE pipes before and after UV exposure were caused by variations in the contents of the crystalline phase (Table 2).

Table 4 Hardness of the HDPE pipes before and after UV exposure

\begin{tabular}{|lll|}
\hline Specimen & Hardness (HD) \\
\cline { 2 - 3 } & Before UV Exposure & After UV Exposure \\
\hline A-R & 56 & 51 \\
\hline A-V & 55 & 49 \\
\hline B-R & 55 & 53 \\
\hline B-V & 60 & 56 \\
\hline C-V & 65 & 61 \\
\hline D-R & 61 & 57 \\
\hline
\end{tabular}

\subsection{Statistical Analysis}

Table 4 and Fig. 9 show that there was variation in tensile strength, modulus of elasticity and hardness of pipes before and after UV exposure. Therefore, a statistical analysis was performed to clarify if there were any significant differences between the measurements. In the present study, one-way analysis of variance (ANOVA) was used. In general, there is no significant difference between measurements if they meet the following conditions: (1) the F-value is less than the F-critical, or (2) the P-value is greater than the selected alpha level (0.05). As shown in Tables 5, 6 and 7, the $F$ value is less than the critical $F$ value and the $P$ value is greater than 0.05 for tensile strength, modulus of elasticity and hardness before and after exposure to UV. It is important to emphasize that there was no statistically significant difference in these measurements before and after UV exposure. Therefore, the tensile strength, modulus of elasticity and hardness of pipes can be considered relatively unchanged after UV exposure 
Table 5

One-way ANOVA of tensile strength before and after UV exposure

\begin{tabular}{|llllllll|}
\hline Specimen & Description & Sum of squares & df & Mean square & F-value & P-value & F-critical \\
\hline \multirow{2}{*}{ A-R } & Between groups & 7.5 & 1 & 7.5 & 1.726 & 0.225 & 5.318 \\
\hline & Within groups & 34.9 & 8 & 4.4 & - & - & - \\
\hline & Total & 42.4 & 9 & - & - & - & - \\
\hline A-V & Between groups & 0.4 & 1 & 0.4 & 0.130 & 0.728 & 5.318 \\
\hline & Within groups & 23.4 & 8 & 2.9 & - & - & - \\
\hline & Total & 23.8 & 9 & - & - & - & - \\
\hline B-R & Between groups & 0.4 & 1 & 0.4 & 1.329 & 0.282 & 5.318 \\
\hline & Within groups & 2.1 & 8 & 0.3 & - & - & - \\
\hline & Total & 2.5 & 9 & - & - & - & - \\
\hline B-V & Between groups & 0.004 & 1 & 0.004 & 0.011 & 0.921 & 5.318 \\
\hline & Within groups & 3.047 & 8 & 0.381 & - & - & - \\
\hline & Total & 3.051 & 9 & - & - & - & - \\
\hline C-V & Between groups & 0.001 & 1 & 0.001 & 0.001 & 0.979 & 5.318 \\
\hline & Within groups & 8.939 & 8 & 1.117 & - & - & - \\
\hline D-R & Total & 8.940 & 9 & - & - & - & - \\
\hline & Between groups & 0.1 & 1 & 0.1 & 0.092 & 0.769 & 5.318 \\
\hline & Within groups & 8.1 & 8 & 1.0 & - & - & - \\
\hline & Total & 8.2 & 9 & - & - & - & - \\
\hline
\end{tabular}


Table 6

One-way ANOVA of elastic modulus before and after UV exposure

\begin{tabular}{|llllllll|}
\hline Specimen & Description & Sum of squares & df & Mean square & F-value & P-value & F-critical \\
\hline \multirow{2}{*}{ A-R } & Between groups & 34052.7 & 1 & 34052.7 & 4.959 & 0.068 & 5.987 \\
\hline & Within groups & 41204.7 & 6 & 6867.5 & - & - & - \\
\hline Total & 75257.4 & 7 & - & - & - & - \\
\hline & Between groups & 11166.1 & 1 & 11166.1 & 5.585 & 0.051 & 5.591 \\
\hline & Within groups & 13995.3 & 7 & 1999.3 & - & - & - \\
\hline B-R & Total & 25161.4 & 8 & - & - & - & - \\
\hline & Between groups & 2189.6 & 1 & 2189.6 & 1.589 & 0.254 & 5.987 \\
\hline & Within groups & 8269.9 & 6 & 1378.3 & - & - & - \\
\hline B-V & Total & 10459.5 & 7 & - & - & - & - \\
\hline & Between groups & 382.5 & 1 & 382.5 & 1.399 & 0.282 & 5.987 \\
\hline & Within groups & 1639.7 & 6 & 273.3 & - & - & - \\
\hline Total & 2022.2 & 7 & - & - & - & - \\
\hline C-V & Between groups & 1871.9 & 1 & 1871.9 & 0.403 & 0.549 & 5.987 \\
\hline & Within groups & 27856.6 & 6 & 4642.8 & - & - & - \\
\hline & Total & 29728.5 & 7 & - & - & - & - \\
\hline & Between groups & 7505.4 & 1 & 7505.4 & 2.061 & 0.211 & 6.608 \\
\hline & Within groups & 18209.5 & 5 & 3641.9 & - & - & - \\
\hline & Total & 25714.9 & 6 & - & - & - & - \\
\hline
\end{tabular}


Table 7

One-way ANOVA of hardness before and after UV exposure

\begin{tabular}{|llllllll|}
\hline Specimen & Description & Sum of squares & df & Mean square & F-value & P-value & F-critical \\
\hline \multirow{2}{*}{ A-R } & Between groups & 40.8 & 1 & 40.8 & 2.065 & 0.201 & 5.987 \\
\hline & Within groups & 118.7 & 6 & 19.8 & - & - & - \\
\hline & Total & 159.5 & 7 & - & - & - & - \\
\hline A-V & Between groups & 70.5 & 1 & 70.5 & 4.342 & 0.082 & 5.987 \\
\hline & Within groups & 97.5 & 6 & 16.2 & - & - & - \\
\hline & Total & 168.0 & 7 & - & - & - & - \\
\hline B-R & Between groups & 7.5 & 1 & 7.5 & 1.875 & 0.220 & 5.987 \\
\hline & Within groups & 24 & 6 & 4.0 & - & - & - \\
\hline & Total & 31.5 & 7 & - & - & - & - \\
\hline B-V & Between groups & 22.5 & 1 & 22.5 & 4.588 & 0.076 & 5.987 \\
\hline & Within groups & 29.5 & 6 & 4.9 & - & - & - \\
\hline & Total & 52.0 & 7 & - & - & - & - \\
\hline C-V & Between groups & 28.0 & 1 & 28.0 & 5.708 & 0.054 & 5.987 \\
\hline & Within groups & 29.5 & 6 & 4.9 & - & - & - \\
\hline Total & 57.5 & 7 & - & - & - & - \\
\hline & Between groups & 21.1 & 1 & 21.1 & 3.992 & 0.093 & 5.987 \\
\hline & Within groups & 31.8 & 6 & 5.3 & - & - & - \\
\hline & Total & 52.9 & 7 & - & - & - & - \\
\hline
\end{tabular}

\section{Discussion}

The use of recycled HDPE pipes is of current interest given the sources of recycling material. Compared to virgin pipes, recycled pipes are more sustainable and cost-effective. Using recycled plastics can reduce a product's carbon footprint. Indeed, a product with 100\% recycled content would have a carbon footprint $24 \%$ smaller [25]. Recycling products can reduce the use of raw materials, energy requirements, water consumption, and greenhouse-gas emissions in the production process $[25,26]$. Our study investigated the effect of UV radiation on the properties of recycled and virgin HDPE pipes. Table 8 shows that UV radiation produced only small changes in the pipe surface, and it did not significantly affect the pipes made with virgin or recycled material. 
Table 8

The effect of UV radiation on the pipes made from recycled or virgin HDPE

\begin{tabular}{|c|c|c|c|c|c|c|c|c|}
\hline \multirow{2}{*}{$\begin{array}{l}\text { Type of } \\
\text { HDPE }\end{array}$} & \multirow[t]{2}{*}{ Specimen } & \multicolumn{5}{|c|}{ Before and After UV Exposure } & \multirow[b]{2}{*}{$\begin{array}{l}\text { Elastic } \\
\text { modulus }\end{array}$} & \multirow[b]{2}{*}{ Hardness } \\
\hline & & FTIR & SEM & $\begin{array}{l}\text { Degree of } \\
\text { crystallinity }\end{array}$ & $\begin{array}{l}\text { Tensile } \\
\text { strength }\end{array}$ & $\begin{array}{l}\text { Elongation } \\
\text { at break }\end{array}$ & & \\
\hline \multirow[t]{3}{*}{ Recycled } & $A-R$ & $\sqrt{ }$ & प & $\square$ & प & $\sqrt{ }$ & $\square$ & प \\
\hline & B-R & $\sqrt{ }$ & प & प & प & $\square$ & प & प \\
\hline & D-R & $\sqrt{ }$ & $\sqrt{ }$ & $\square$ & प & $\sqrt{ }$ & $\square$ & प \\
\hline \multirow[t]{3}{*}{ Virgin } & $A-V$ & $\sqrt{ }$ & $\sqrt{ }$ & प & प & $\sqrt{ }$ & प & 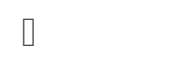 \\
\hline & $B-V$ & $\sqrt{ }$ & प & प & प & $\square$ & प & प \\
\hline & $C-V$ & $\sqrt{ }$ & प & प & $\square$ & $\sqrt{ }$ & प & प \\
\hline \multicolumn{9}{|c|}{ Note: $\mathbb{\nabla}=$ no changes or remained constant; $\sqrt{ }=$ negligible changes. } \\
\hline \multicolumn{9}{|c|}{ List of Figures } \\
\hline
\end{tabular}

- FTIR analysis shows that negligible structural modifications occurred on the top surface after UV exposure. In the case of manufacturer $A$, the peak of carbonyl stretching vibration at $1717 \mathrm{~cm}^{-1}$ was observed with virgin pipes (A-V). In contrast, the peak of carbonyl stretching vibration did not appear for either recycled or virgin pipes from manufacturer $B$. This peak was detected for recycled pipes from manufacturer D. In addition, the peak of polyhydroxyl stretch at $3380 \mathrm{~cm}^{-1}$ was detected in all the pipes. The SEM results were similar for specimens after UV exposure. When the scanning width was $10 \mu \mathrm{m}$, some cracks appeared on the surface of virgin pipes (A-V) from manufacturer $A$ and recycled pipes (DR) from manufacturer $D$. This was not observed for either recycled or virgin pipes from manufacturer $B$.

- DSC analysis shows that the melting points for the recycled and virgin pipes from the same manufacturer (only A and B) were the same before and after UV exposure. The degree of crystallinity remained constant for both recycled and virgin pipes after 3600 hours of UV exposure. In general, the presence of impurities during the manufacturing process caused the recycled pipes to easily absorb UV radiation compared to the virgin pipes. However, based on OIT measurements, it appears that antioxidants were consumed as a result of UV exposure. In other words, they prevented the formation of free radicals. Consequently, the thermal properties of recycled and virgin pipes remained constant under the effect of UV radiation.

- The tensile strength, elastic modulus, and hardness of the HDPE pipes made with recycled or virgin material were relatively unaffected after UV exposure. In contrast, the elongation at break decreased from $12-87 \%$ of the initial elongation at break for both recycled and virgin pipes.

Based on the results, the pipes are made from recycled or virgin resins were relatively unaffected by UV radiation. These results are in good agreement with the finding from other studies [17-20,43]. It should be 
emphasized that the presence of carbon black, antioxidants, and UV stabilizers had a synergistic effect on the UV stabilization of the recycled and virgin HDPE pipes.

\section{Conclusions}

The effects of UV radiation on the chemical, microstructure, thermal, and tensile properties of new corrugated HDPE pipes made with or without recycled resins used in road drainage systems were assessed. The following conclusions can be drawn from the study:

1. The incorporation of carbon black, antioxidants, UV stabilizers helped limit the formation of free radicals during the aging process. Therefore, it prevented the degradation of the HDPE pipes during UV exposure.

2. Before being exposed to UV radiation, the recycled and virgin pipes had the same chemical and morphological structures. Small changes, probably due to the presence of a contaminant on the surface of certain pipes, were observed in FTIR and SEM analysis after UV exposure.

3. While the antioxidants in the pipes were partly consumed due to UV exposure, the minimum 20-minute OIT requirement for withstanding oxidation was met. In addition, statistical analysis using one-way analysis of variance (ANOVA) shows that there was no significant difference between measures of tensile strength, modulus of elasticity and hardness before and after exposure to UV. Therefore, it can be considered that the pipes made from virgin or recycled resins maintained adequate thermal (melting point, degree of crystallinity) and mechanical (tensile strength, elastic modulus, hardness) properties after exposure to UV radiation. The elongation at break was, however, reduced. Achieving this level of UV protection required a minimum of $2-4 \%$ of carbon black added to the resin compound, depending on the presence or absence of other antioxidants or UV stabilizers.

4. The findings of the current study would be the premise upon which recycled HDPE becomes one of the most widely used materials in the future. On the other hand, recycled HDPE should be used for floating solar applications where the material is subjected to direct sunlight.

\section{Declarations}

\section{Data Availability Statement}

Some or all data, models, or code that support the findings of this study are available from the corresponding author upon reasonable request.

\section{Declaration of Competing Interest}

The authors declare that they have no known competing financial interests or personal relationships that could have appeared to influence the work reported in this paper.

\section{Acknowledgments}

This research received financial support from the Natural Science and Engineering Research Council of Canada (NSERC), the Ministry of Transportation of Quebec (MTQ), and the University of Sherbrooke 
Research Centre on Composite Materials (CRUSMaC). The authors are also grateful to the technical staff of the structural laboratory at the University of Sherbrooke, especially Jérôme Lacroix and Steven MacEachern, for their technical assistance.

\section{References}

1. Gassman SL, Schroeder AJ, Ray RP, “Field Performance of High Density Polyethylene Culvert Pipe,” J. Transp. Eng., vol. 131, no. 2, pp. 160-167, Feb. 2005, doi: 10.1061/(ASCE)0733-947X(2005)131:2(160)

2. P pipe institute PPI Handbook, “Chapter 3 - Material Properties,” p. 61, 2008

3. Petroff LJ, “Occasional and Recurring Surge Design Considerations for HDPE Pipe,” in Pipelines 2013, Fort Worth, Texas, United States, Jun. 2013, pp. 161-170, doi: 10.1061/9780784413012.014

4. Rubeiz CG (Jul. 2004) "Case Studies on the Use of HDPE Pipe for Municipal and Industrial Projects in North America. In: " in Pipeline Engineering and Construction. California, United States, San Diego, pp 1-10. doi:10.1061/40745(146)22

5. Ortega R, Klopfenstein C, Morris A (Jul. 2004) “HDPE, An Alternative with Limitations; Houston's Experience. In: " in Pipeline Engineering and Construction. California, United States, San Diego, pp 1-10. doi:10.1061/40745(146)39

6. Nguyen KQ, Mwiseneza C, Mohamed K, Cousin P, Robert M, Benmokrane B (Apr. 2021) Long-term testing methods for HDPE pipe - advantages and disadvantages: A review. Eng Fract Mech 246:107629. doi:10.1016/j.engfracmech.2021.107629

7. Qureshi FS, Hamid SH, Maadhah AG, Amin MB, “Weather-Induced Degradation of Plastic Pipes,” Polymer-Plastics Technology and Engineering, vol. 28, no. 7-8, pp. 663-670, Sep. 1989, doi: $10.1080 / 03602558908049821$

8. Stuart S, "Evaluation of HDPE and PVC Pipes Used for Cross-drains in Highway Construction," PhD Thesis, Auburn University, 2011

9. Zhao JQ, Kuraoka S, Baker THW, Gu P, Masson J-F, Boudreau S, Brousseau RJ, “Durability and Performance of Gravity Pipes: State-of-the-art Literature Review”, Institute for Research in Construction, 1998. https://nrc-publications.canada.ca/eng/view/accepted/?id=3f56015a-909e-45fb-9b8ac8e536b96d54

10. H. PPI, “Second Edition Handbook of PE Pipe I HDPE Handbook,” 2008. https://plasticpipe.org/publications/pe-handbook.html

11. Rabek JF (1995) "Physical aspects of the photodegradation of polymers. In: " in Polymer Photodegradation. Springer Netherlands, Dordrecht, pp 1-23. doi:10.1007/978-94-011-1274-1_1

12. Becerra AFC, d'Almeida JRM, “UV Effects on the Tensile and Creep Behaviour of HDPE," Polymers and Polymer Composites, vol. 25, no. 5, pp. 327-332, Jun. 2017, doi: 10.1177/096739111702500502

13. Roy PK, Surekha P, Raman R, Rajagopal C, "Investigating the role of metal oxidation state on the degradation behaviour of LDPE," Polymer Degradation and Stability, vol. 94, no. 7, pp. 1033-1039, Jul. 2009, doi: 10.1016/j.polymdegradstab.2009.04.025 
14. Koutny M, Lemaire J, Delort A-M, "Biodegradation of polyethylene films with prooxidant additives," Chemosphere, vol. 64, no. 8, pp. 1243-1252, Aug. 2006, doi: 10.1016/j.chemosphere.2005.12.060

15. BNQ 3624-120 (2016) "Tuyaux à profil ouvert et à paroi intérieure lisse en polyéthylène (PE) et raccords en polyéthylène (PE) pour les égouts pluviaux, les ponceaux et le drainage des sols. " Bureau de Normalisation du Québec

16. ASTM D4218 (2015) "Standard Test Method for Determination of Carbon Black Content in Polyethylene Compounds by the Muffle-Furnace Technique. " ASTM International, West Conshohocken

17. Attwood J, Philip M, Hulme A, Williams G, Shipton P, "The effects of ageing by ultraviolet degradation of recycled polyolefin blends," Polymer Degradation and Stability, vol. 91, no. 12, pp. 3407-3415, Dec. 2006, doi: 10.1016/j.polymdegradstab.2006.04.025

18. Maria R et al (Oct. 2011) Monitoring the influence of different weathering conditions on polyethylene pipes by IR-microscopy. Polym Degrad Stab 96(10):1901-1910.

doi:10.1016/j.polymdegradstab.2011.07.004

19. Jassim KA, Jassim WH, Mahdi SH (2017) The effect of sunlight on medium density polyethylene Water pipes. Energy Procedia 119:650-655. doi:10.1016/j.egypro.2017.07.091

20. Jiang T, Qi Y, Wu Y, Zhang J, "Application of antioxidant and ultraviolet absorber into HDPE: Enhanced resistance to UV irradiation," e-Polymers, vol. 19, no. 1, pp. 499-510, Oct. 2019, doi: 10.1515/epoly2019-0053

21. Thomas RW (2011) Performance of corrugated pipe manufactured with recycled polyethylene content, vol 696. Transportation Research Board

22. Pluimer M, Sprague J, Thomas R, McCarthy L, Welker A, Sargand S, White K, "Field Performance of Corrugated Pipe Manufactured with Recycled Polyethylene Content," 2018

23. Pluimer ML, "Evaluation of corrugated HDPE pipes manufactured with recycled content in commuter rail applications," Villanova University, 2016

24. Shaheen ET, “Long term performance of corrugated HDPE pipes produced with post-consumer recycled materials under constant deflection," Ohio University, 2018

25. Dormer A, Finn DP, Ward P, Cullen J (Jul. 2013) Carbon footprint analysis in plastics manufacturing. J Clean Prod 51:133-141. doi:10.1016/j.jclepro.2013.01.014

26. Korhonen MR, Dahlbo H (2007) “Reducing greenhouse gas emissions by recycling plastics and textiles into products. " Finnish Environment Institute, Helsinki

27. ASTM D792 (2013) "Standard test methods for density and specific gravity (relative density) of plastics by displacement. " ASTM International, West Conshohocken

28. ASTM D1238 (2013) "Standard Test Method for Melt Flow Rates of Thermoplastics by Extrusion Plastometer. " ASTM International, West Conshohocken

29. ASTM D5805-00 (2019) “Standard Test Methods for Rubber - Determination of Carbon Black in Masterbatches. " ASTM International, West Conshohocken

30. ASTM E2550 (2017) "Standard Test Methods for Thermal Stability by Thermogravimetry. " ASTM International, West Conshohocken 
31. ASTM D638 (2014) "Standard Test Methods for Tensile Properties of Plastics. " ASTM International, West Conshohocken

32. ASTM D4329 (2013) "Standard Practice for Fluorescent Ultraviolet (UV) Lamp Apparatus Exposure of Plastics. " ASTM International, West Conshohocken

33. Hitachi High-Tech, "Application Note: Thermal Analysis- DSC Measurement of Polyethylene_No_26." Hitachi High-Tech Science Corporation, 1986, [Online]. Available: https://www.hitachihightech.com/file/global/pdf/products/science/appli/ana/thermal/application_TA_026e.pdf

34. ASTM D3895 (2019) "Standard Test Method for Oxidative-Induction Time of Polyolefins by Differential Scanning Calorimetry. " ASTM International West Conshohock-en, PA

35. ASTM D2240 (2015) “Standard Test Method for Rubber Property-Durometer Hardness. " ASTM International, West Conshohocken

36. Khan SM et al (Oct. 2016) 2D Carbon Fiber Reinforced High Density Polyethylene Multi-Layered Laminated Composite Panels: Structural, Mechanical, Thermal, and Morphological Profile. Journal of Materials Science Technology 32(10):1077-1082. doi:10.1016/j.jmst.2016.06.011

37. Luongo JP (Jan. 1960) Infrared study of oxygenated groups formed in polyethylene during oxidation. J Polym Sci 42(139):139-150. doi:10.1002/pol.1960.1204213916

38. Wang S, Zhang J, Liu L, Yang F, Zhang Y, "Evaluation of cooling property of high density polyethylene (HDPE)/titanium dioxide (TiO2) composites after accelerated ultraviolet (UV) irradiation," Solar Energy Materials and Solar Cells, vol. 143, pp. 120-127, Dec. 2015, doi: 10.1016/j.solmat.2015.06.032

39. Hoàng EM, Lowe D, "Lifetime prediction of a blue PE100 water pipe," Polymer Degradation and Stability, vol. 93, no. 8, pp. 1496-1503, 2008, doi: 10.1016/j.polymdegradstab.2008.05.008

40. Hassinen J (May 2004) Deterioration of polyethylene pipes exposed to chlorinated water. Polym Degrad Stab 84(2):261-267. doi:10.1016/j.polymdegradstab.2003.10.019

41. Weon J-I (Jan. 2010) Effects of thermal ageing on mechanical and thermal behaviors of linear low density polyethylene pipe. Polym Degrad Stab 95(1):14-20.

doi:10.1016/j.polymdegradstab.2009.10.016

42. Kadhim LF (2017) Mechanical Properties of High-Density Polyethylene/Chromium Trioxide under Ultraviolet Rays. International Journal of Applied Engineering Research 12(10):2517-2526

43. Javadi Y, Hosseini MS, Aghjeh MKR (2014) The effect of carbon black and HALS hybrid systems on the UV stability of high-density polyethylene (HDPE). Iran Polym J 23(10):793-799. doi:10.1007/s13726014-0275-2

\section{Figures}



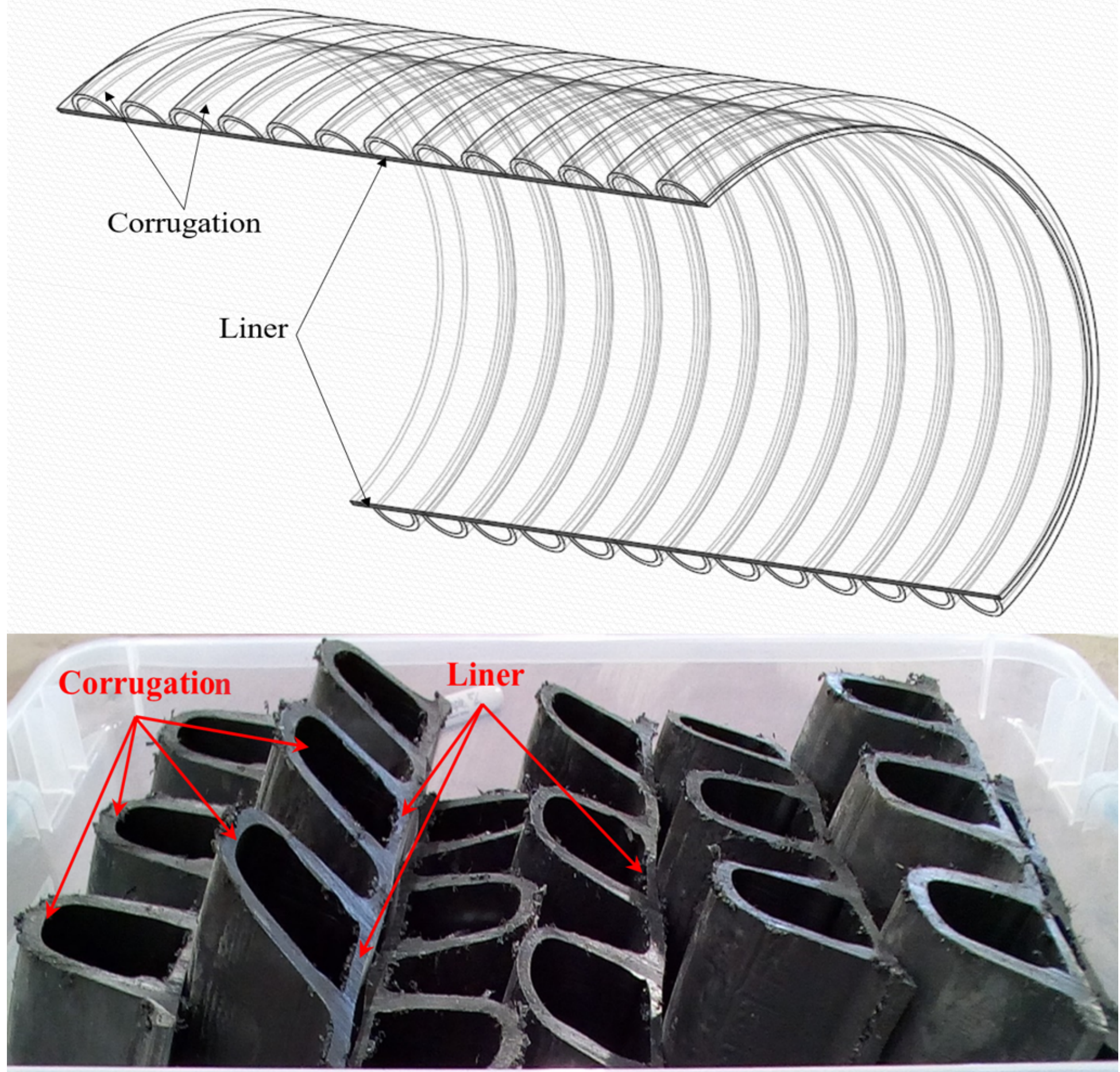

Figure 1

A sectional view of an HDPE pipe showing the location of the corrugation and liner. 


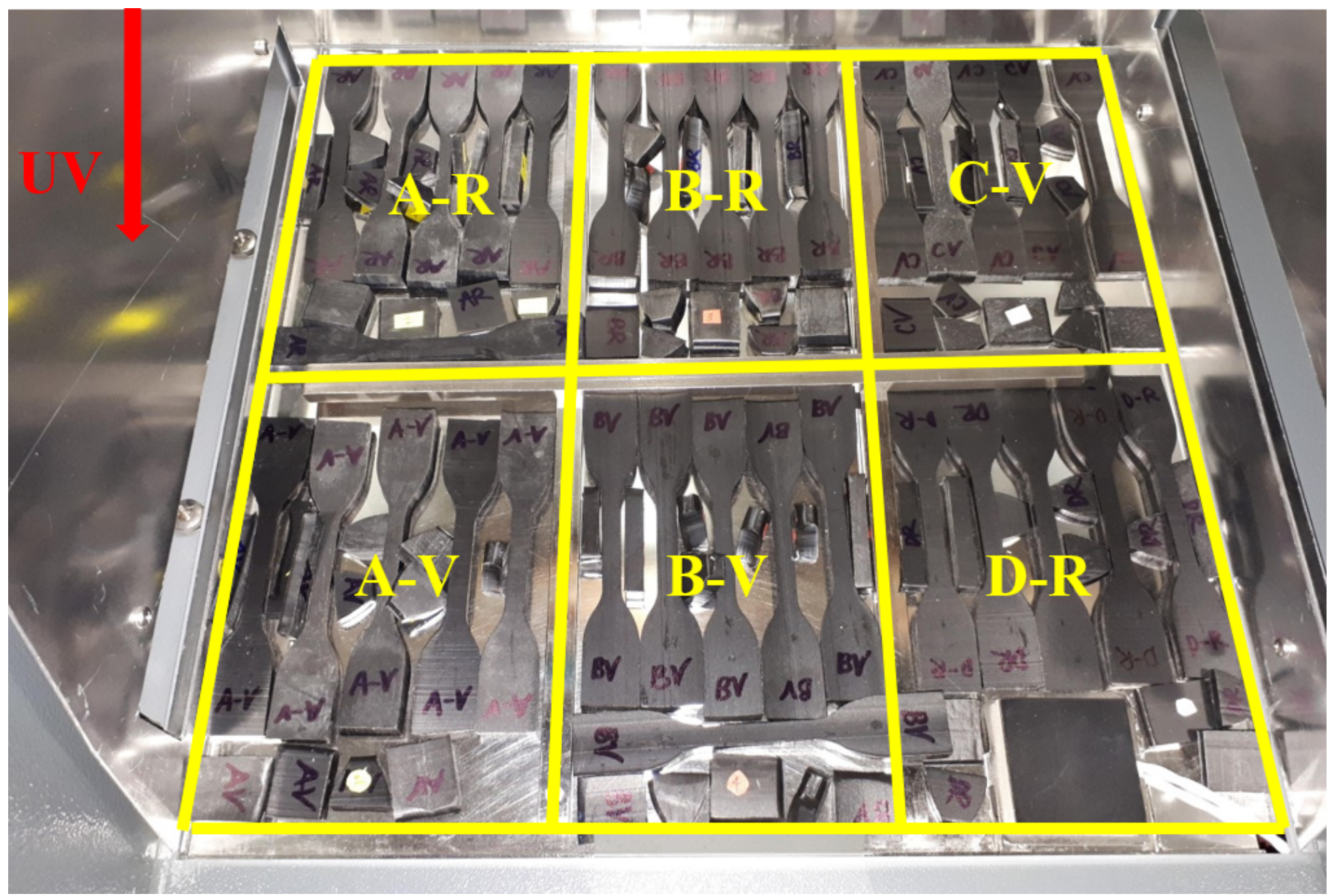

Figure 2

Specimens placed for aging in the UV chamber. 


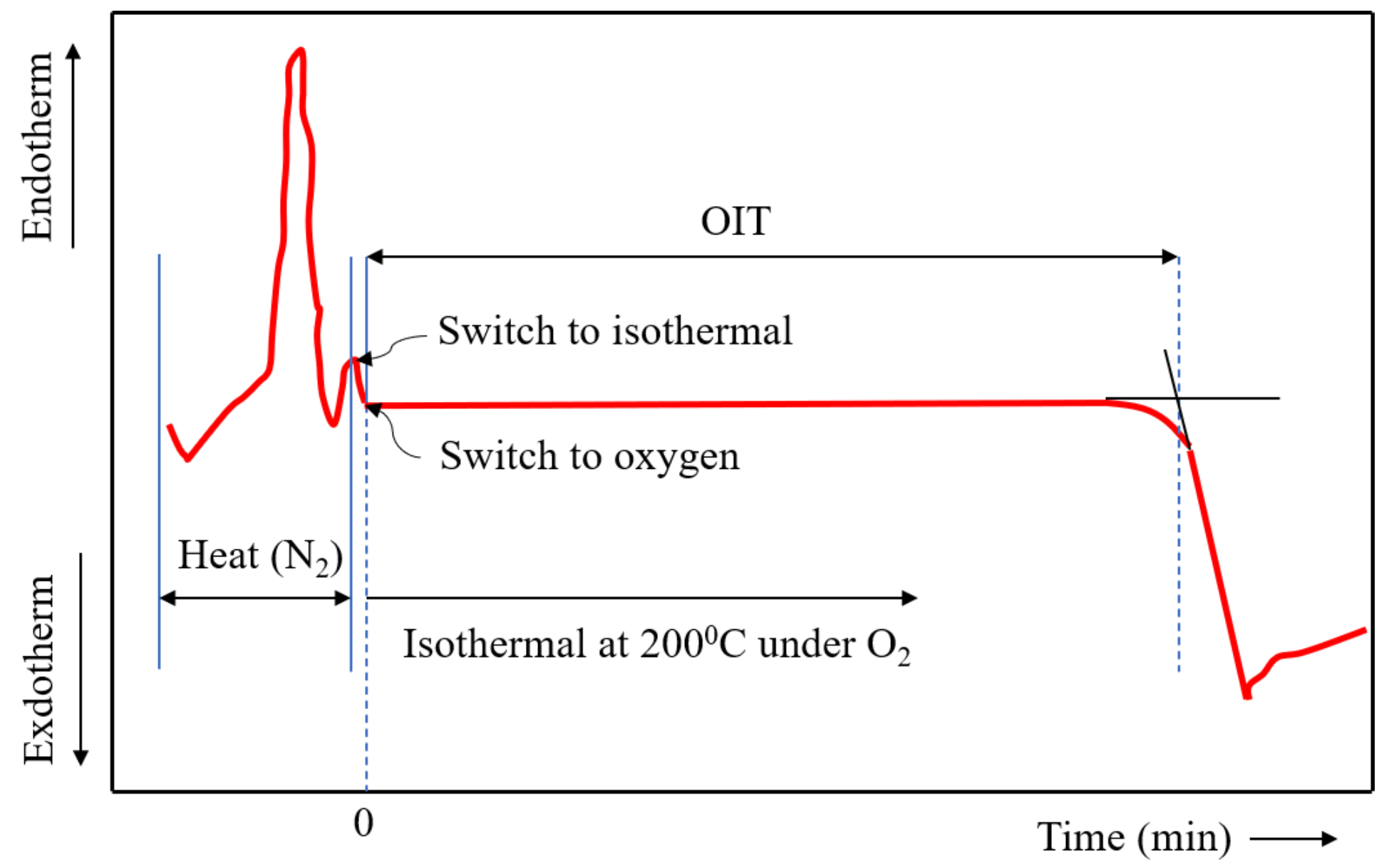

Figure 3

Evaluation of OIT from recorded time-based thermal curve.

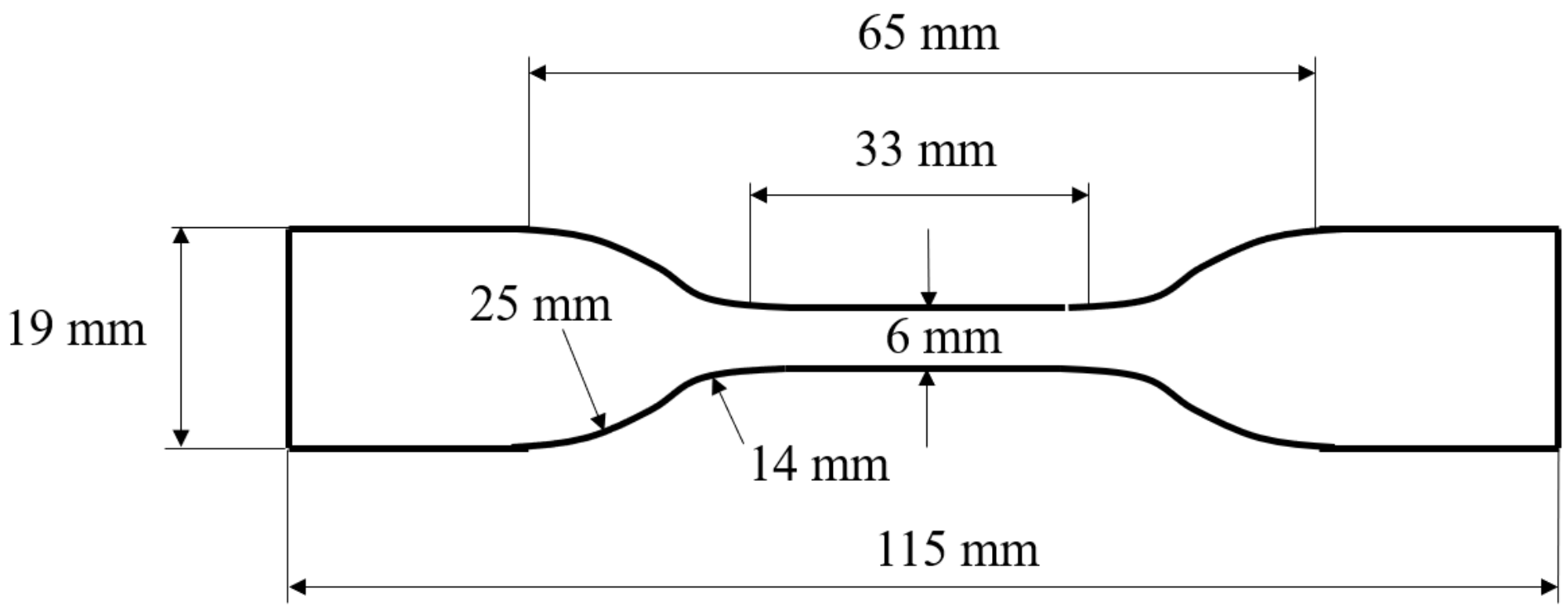

Figure 4

Typical dog-bone specimens for evaluating tensile strength. 

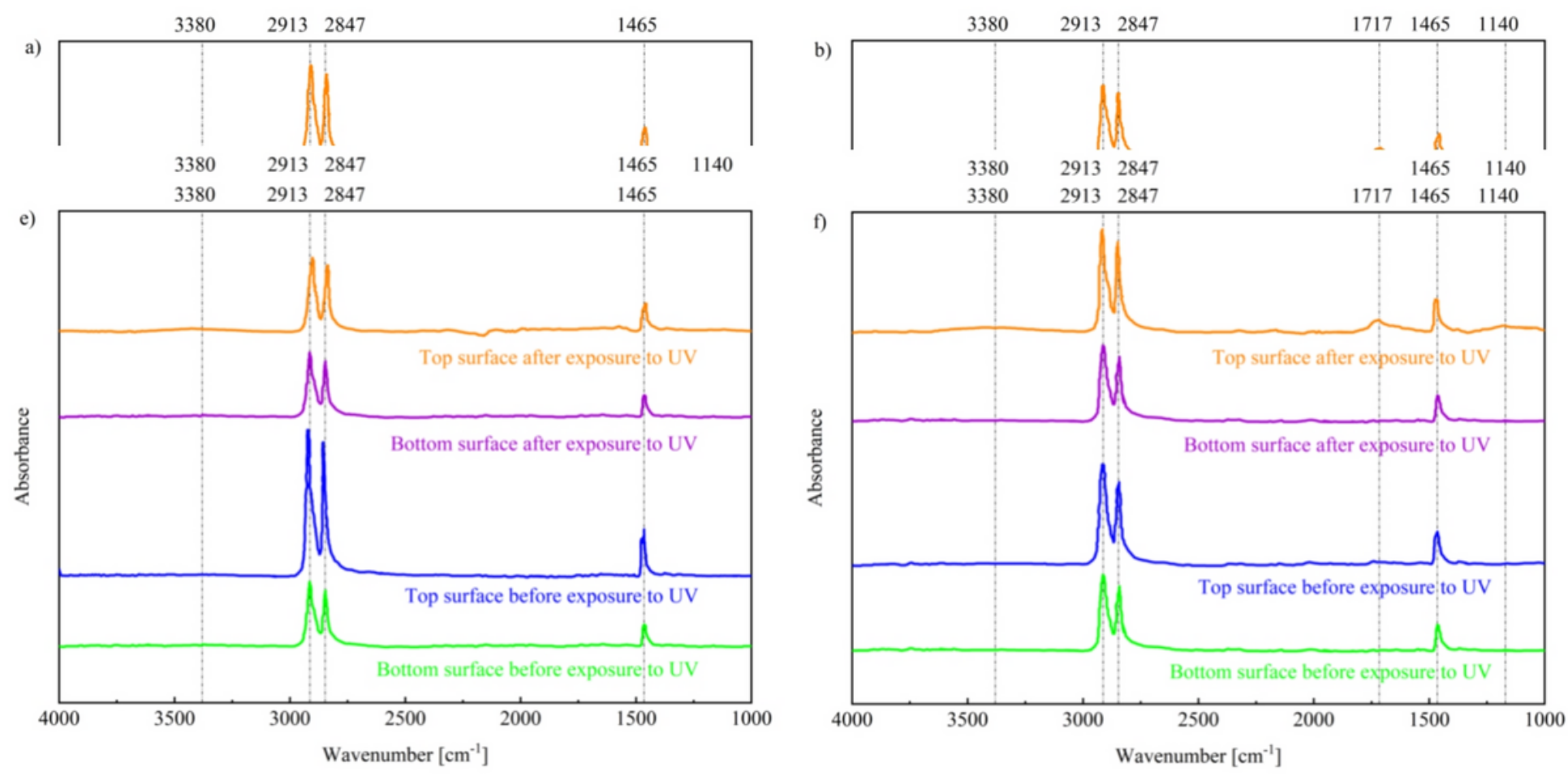

Figure 5

FTIR spectra of HDPE pipes before and after UV exposure: a) A-R, b) A-V, c) B-R, d) B-V, e) C-V, and f) D-R. 


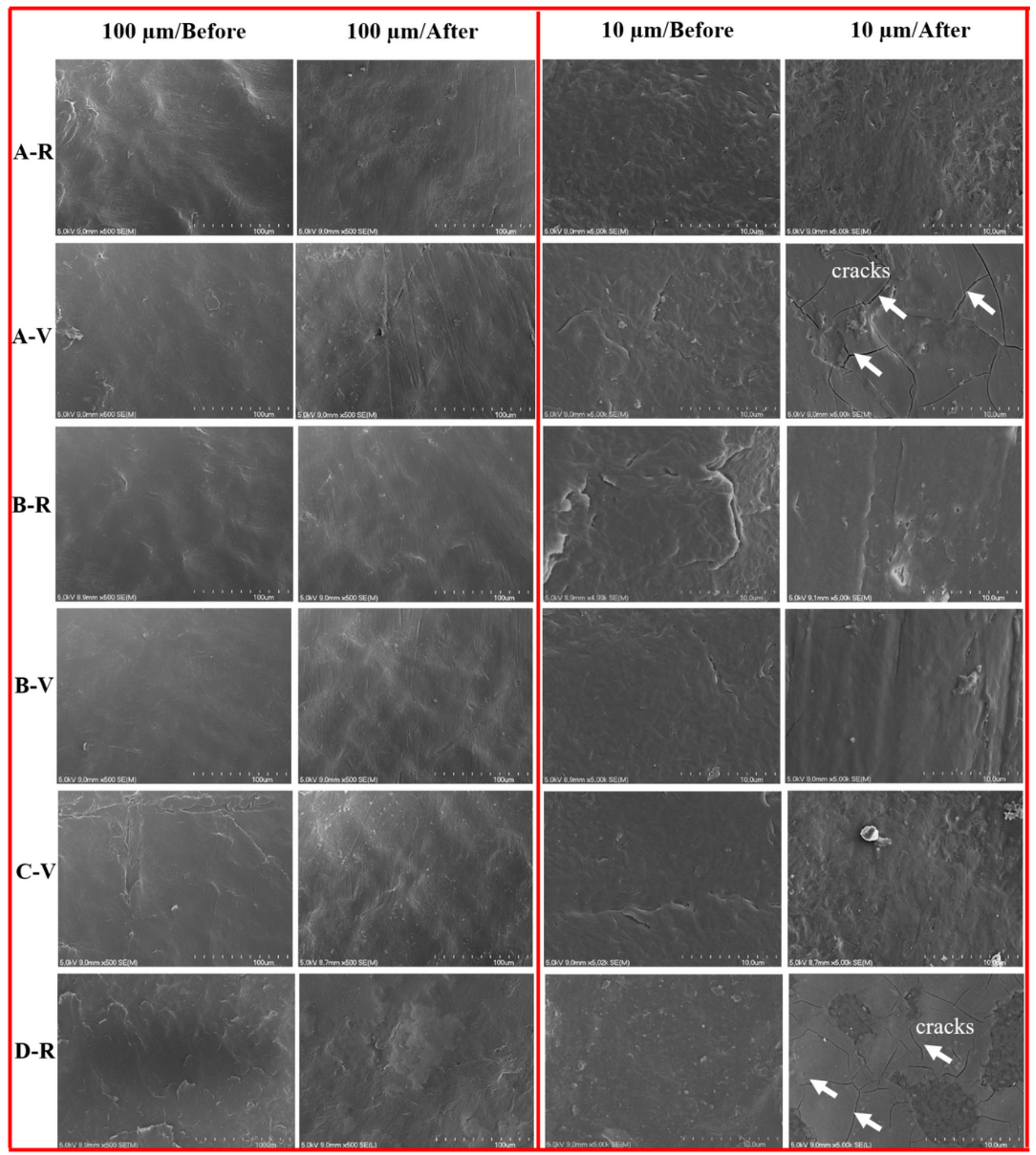

Figure 6

Morphological structure of HDPE pipes before and after UV exposure at scan widths of $100 \mu \mathrm{m}$ and $10 \mu \mathrm{m}$. 


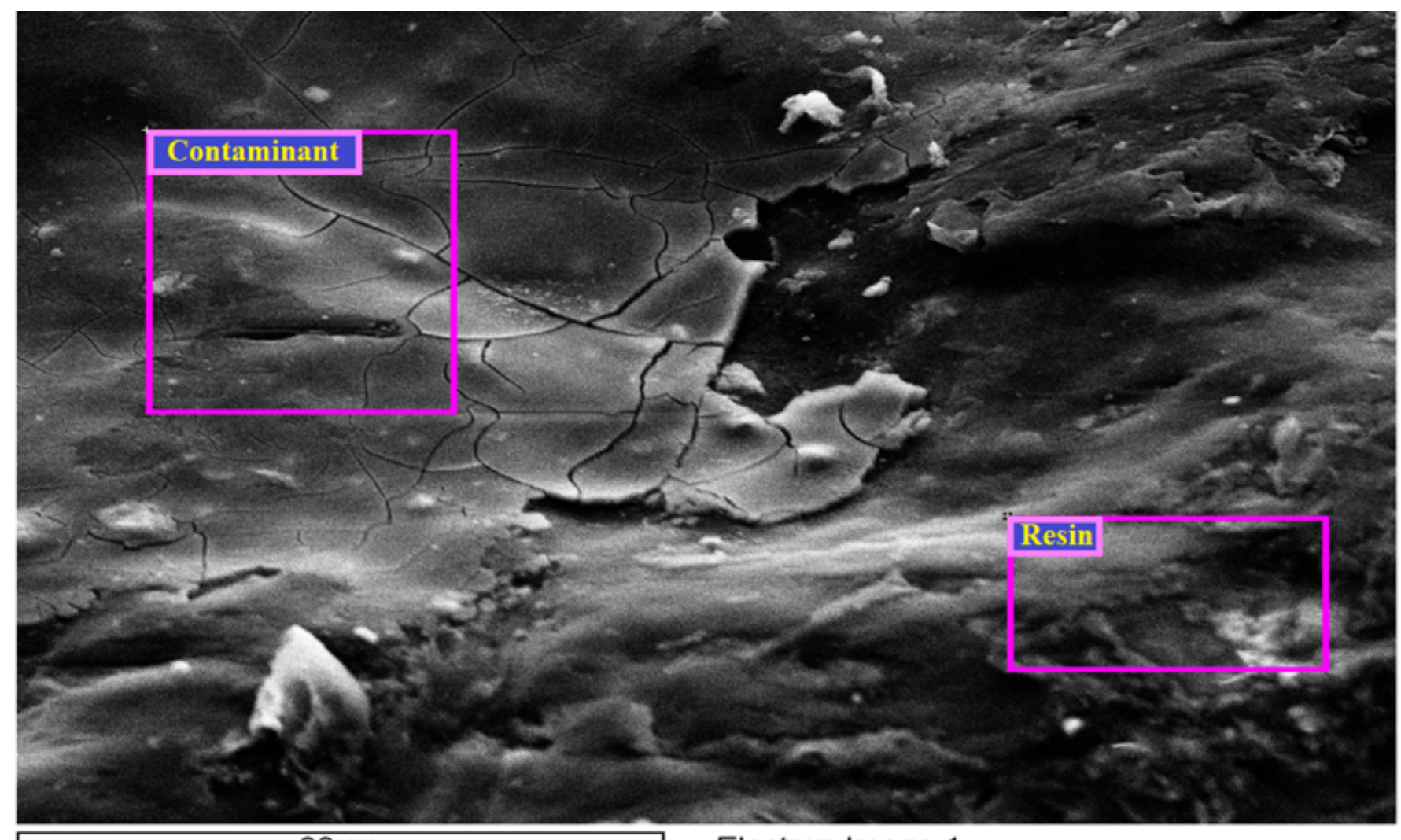

$30 \mu \mathrm{m}$

Electron Image 1

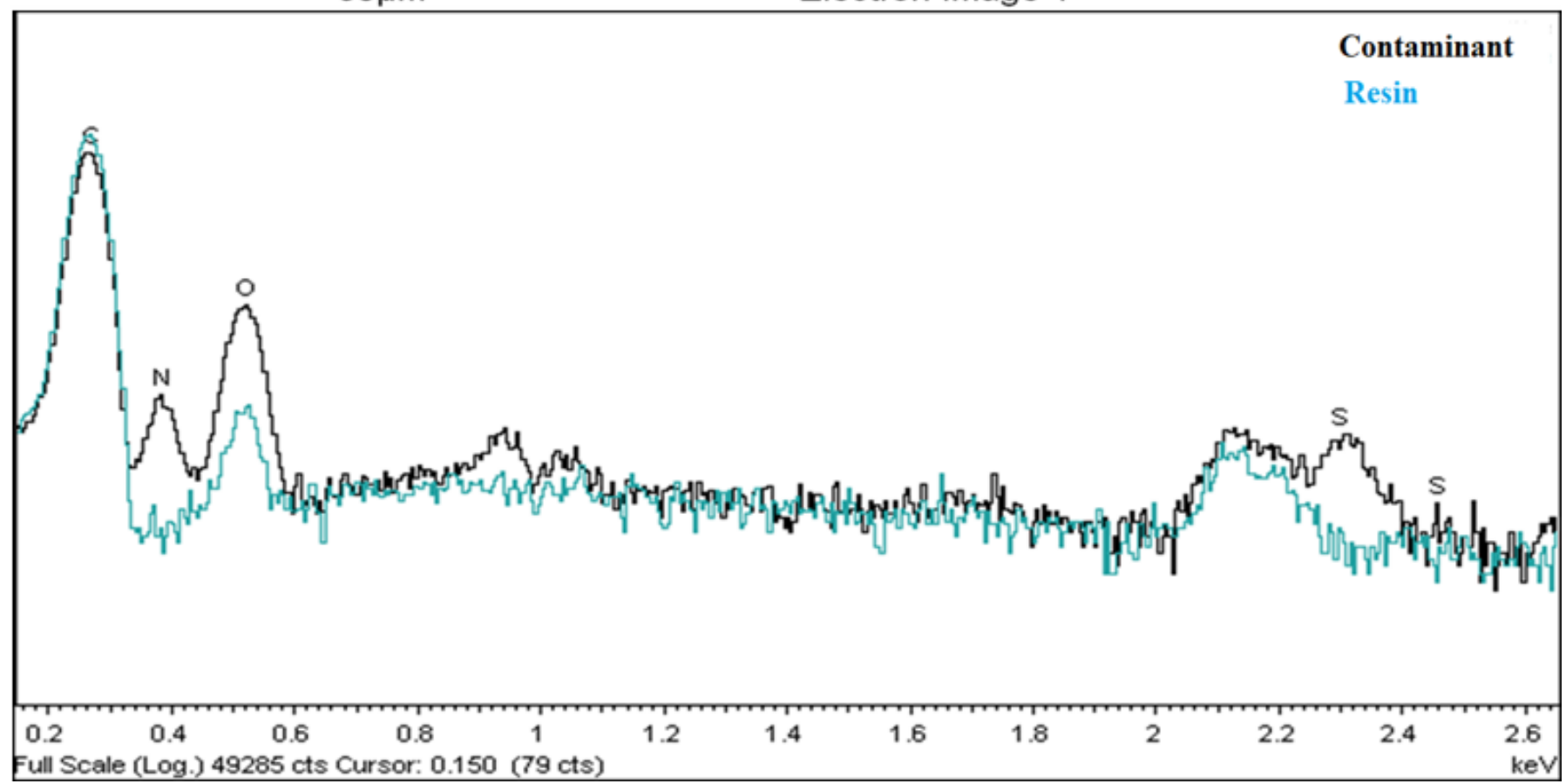

Figure 7

EDS analysis and chemical composition of lightest (contaminant) and darkest areas of A-V and D-R pipes. 

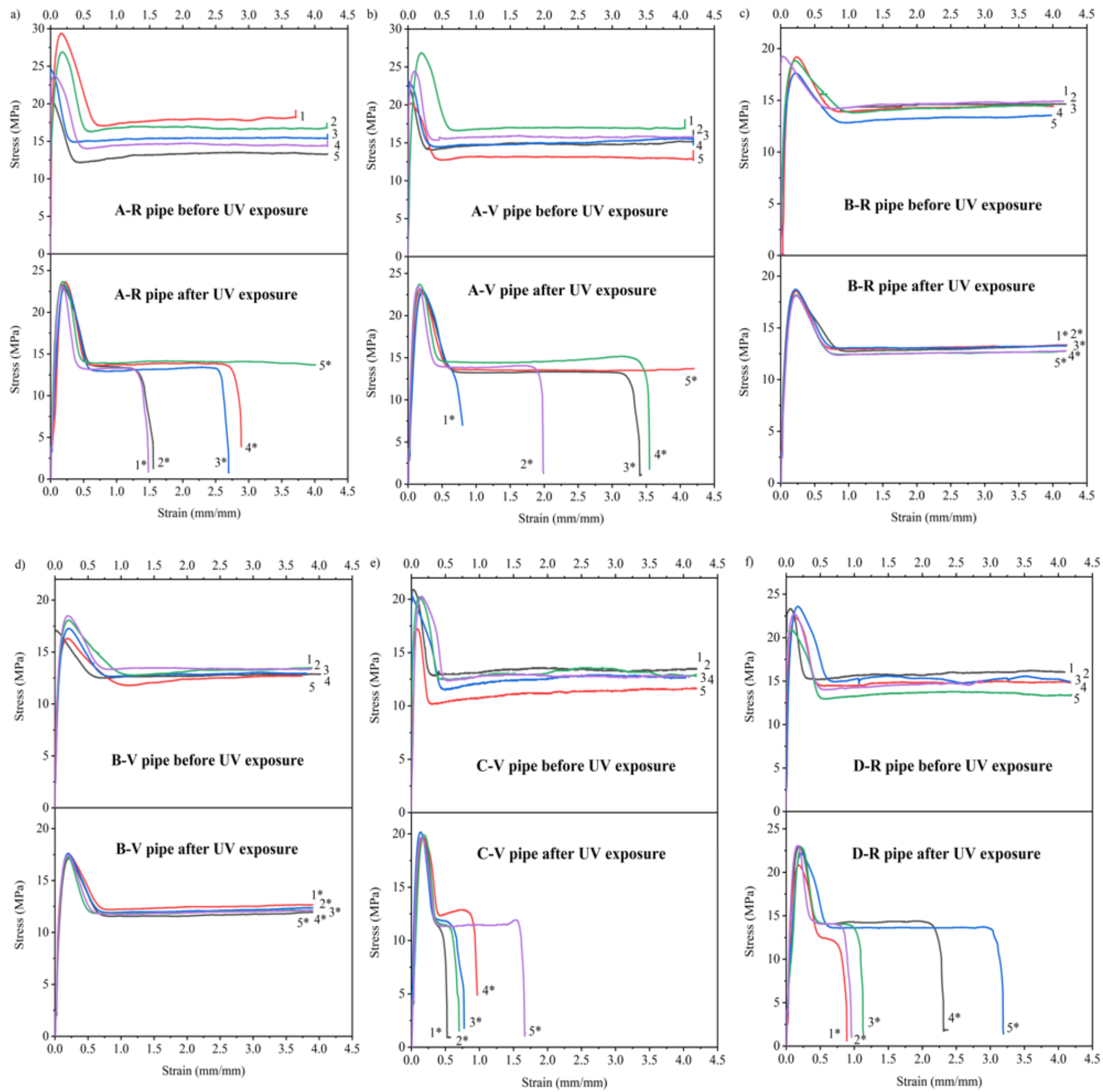

\section{Figure 8}

Typical tensile stress-strain behaviors of the HDPE pipes before and after UV exposure: a) A-R, b) A-V, c) B$R$, d) $B-V, e) C-V$, and f) D-R. 

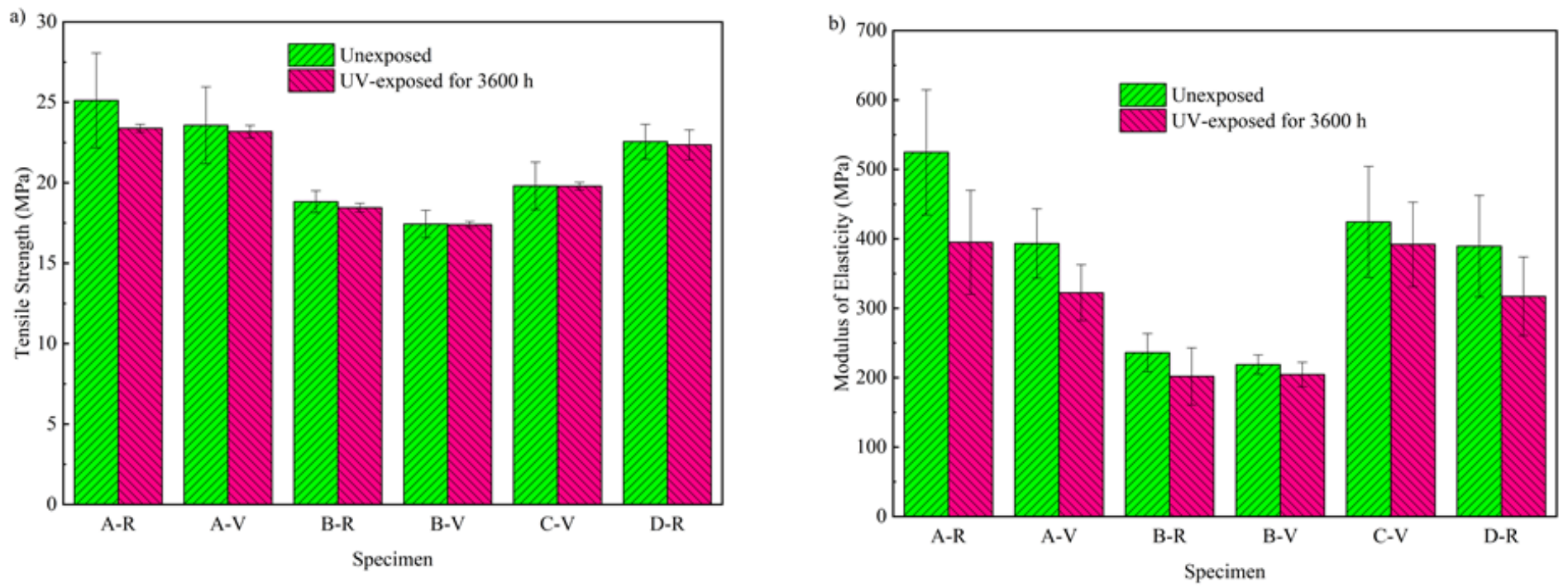

Figure 9

Mechanical properties of the HDPE pipes before and after UV exposure: a) tensile strength and b) modulus of elasticity. 